\title{
Phenytoin-Induced Elevation of the Intracellular Calcium Concentration by Stimulation of Calcium-Sensing Receptors in Gingival Fibroblasts*
}

\author{
Toshimi Hattori ${ }^{1}$, Keisuke Nakano ${ }^{2}$, Toshiyuki Kawakami ${ }^{2 \#}$ \\ ${ }^{1}$ Department of Dental Pharmacology, Matsumoto Dental University, Shiojiri, Japan; ${ }^{2}$ Hard Tissue Pathology Unit, Institute of Oral \\ Science, Matsumoto Dental University, Shiojiri, Japan. \\ Email: "kawakami@po.mdu.ac.jp
}

Received January $17^{\text {th }}, 2013$; revised March $4^{\text {th }}, 2013$; accepted April $15^{\text {th }}, 2013$

Copyright (C) 2013 Toshimi Hattori et al. This is an open access article distributed under the Creative Commons Attribution License, which permits unrestricted use, distribution, and reproduction in any medium, provided the original work is properly cited.

\begin{abstract}
Background: The mechanism concerning gingival overgrowth as a side effect of phenytoin, a therapeutic drug for epilepsy has been still unclear. As one of mechanisms, by measuring the intracellular calcium concentration $\left(\left[\mathrm{Ca}^{2+}\right] \mathrm{i}\right)$ of the gingival fibroblasts, it has been advocated that there is relationship between gingival overgrowth and phenytoin-induced alterations in the $\left[\mathrm{Ca}^{2+}\right] \mathrm{i}$ in gingival fibroblasts. To confirm that phenytoin elevates the $\left[\mathrm{Ca}^{2+}\right] \mathrm{i}$, and if so, to find out its mode of action. Methods: The $\left[\mathrm{Ca}^{2+}\right]$ i was measured with the $\mathrm{Ca}^{2+}$-sensitive fluorescent dye fura-2/AM. Cells were soaked in a flexiperm chamber and perfused by a saline. Drugs at appropriate concentrations were added to the perfusate. Results: Phenytoin concentration-dependently elevated the $\left[\mathrm{Ca}^{2+}\right]$ i. NPS2390, a calcium-sensing receptor (CaSR) blocker, significantly suppressed the phenytoin-induced $\left[\mathrm{Ca}^{2+}\right]$ i elevation. U73122, a phospholipase C (PLC) inhibitor, inihibited the phenytoin-induced $\left[\mathrm{Ca}^{2+}\right]$ i elevation. TMB-8, a blocker of inositol triphophate $\left(\mathrm{IP}_{3}\right)$ receptors in ER, significantly depressed the phenytoin-induced $\left[\mathrm{Ca}^{2+}\right]$ i elevation. $m$-3M3FBS, a PLC activator, enhanced the phenytoin-induced $\left[\mathrm{Ca}^{2+}\right] \mathrm{i}$ elevation. From the findings obtained, it is discussed as follows: The $\mathrm{Ca}^{2+}$-free saline and NPS2390, a CaSR antagonist, inhibited the phenytoin-induced $\left[\mathrm{Ca}^{2+}\right]$ i rise; These results indicate that CaSRs exist in gingival fibroblasts and that CaSRs are involved in the phenytoin-induced $\left[\mathrm{Ca}^{2+}\right]$ i rise; U73122 and TMB-8 depressed the phenytoin-induced $\left[\mathrm{Ca}^{2+}\right]$ i elevation and furthermore, $m-3 \mathrm{M} 3 \mathrm{FBS}$ enhanced the phenytoin-induced $\left[\mathrm{Ca}^{2+}\right]$ i elevation, showing that the $\mathrm{Ca}^{2+}$ release from the ER is involved in the phenytoin-induced $\left[\mathrm{Ca}^{2+}\right]$ i elevation. Conclusion: We have concluded that phenytoin elevates the $\left[\mathrm{Ca}^{2+}\right]$ i by activating CaSRs and enhancing the $\mathrm{Ca}^{2+}$ release from the $\mathrm{Ca}^{2+}$ stores in gingival fibroblasts.
\end{abstract}

Keywords: Phenytoin; Calcium-Sensing Receptor; Endoplasmic Reticulum; Gingival Fibroblast; Gingival Overgrowth

\section{Introduction}

Gingival overgrowth as a side effect of phenytoin, a therapeutic drug for epilepsy has been still now observed [1]. However, the mechanism concerning this symptom has been still unclear. Various mechanisms of gingival overgrowth induced by phenytoin have been advocated. It has been thought that there are mainly 2 causes, that is, collagen accumulation and fibroblast proliferation in gingiva. For example, concerning collagen accumulation, gingival overgrowth is due to only increase in collagen or inhibition of its degradation. Narayanan et al. [2] concluded that overproduction of collagen by cells from

${ }^{*}$ The authors declare that they have no conflict of interests to disclose.

\#Corresponding author. phenytoin-induced hyperplastic gingiva results from an increased steady state level of collagen mRNA and not decreased collagen degradation. However, Kanno et al. [3] proposed that collagen accumulation may be attributed to a decrease in its degradation rather than to an increase in collagen synthesis. Furthermore, Akhter et al. [4] also claimed that gingival overgrowth seems to be induced by the disruption of homeostasis of collagen synthesis and degradation in gingival connective tissue, predominantly through the inhibition of collagen phagocytosis of gingival fibroblasts. In addition, concerning fibroblast proliferation, Cockey et al. [5] speculated that drug-induced gingival overgrowth may occur due to direct or indirect stimulation of the proliferation of some 
populations of fibroblasts. González et al. [6] and Kato et al. [7] also proposed the increase in fibroblast proliferation. In contrast, Fujimori et al. [8] reported that a reduced rate of apoptosis contributes to the accumulation of gingival fibroblasts. On the hand, as the other mechanism, by measuring the intracellular calcium concentration $\left(\left[\mathrm{Ca}^{2+}\right] \mathrm{i}\right)$ of the gingival fibroblasts, Modéer et al. [9] have advocated that there is relationship between gingival overgrowth and phenytoin-induced alterations in the $\left[\mathrm{Ca}^{2+}\right] \mathrm{i}$ in gingival fibroblasts.

Nifedipine, an anti-hypertension drug, as well as phenytoin, develops gingival overgrowth. Regarding to nifedipine, we have claimed the involvement of the $\left[\mathrm{Ca}^{2+}\right] \mathrm{i}$ in its action and that recently advocated the modified "Calcium trigger theory" [10]. That is, we have inferred that nifedipine evokes gingival overgrowth by triggering the $\left[\mathrm{Ca}^{2+}\right] \mathrm{i}$ elevation in gingival fibroblasts.

Thus, the present study aims to confirm that phenytoin elevates the $\left[\mathrm{Ca}^{2+}\right]$ i similarly to nifedipine, and identufy the mode of action. Above all, we investigated actions of modulators of calcium-sensing recaptors (CaSRs) and the transmission from CaSRs to endoplasmic reticula (ER), since it is reported that CaSRs are related to cell proliferation [11] and that signals from CaSRs are transmitted to ER $[12,13]$.

\section{Materials and Methods}

\subsection{Cell Culture}

Normal human gingival fibroblast Gin-1 cells were obtained from Dainippon Pharmaceutical Co. Ltd. (Osaka, Japan). Cells were cultured for 3 - 6 days in Dulbecco's modified Eagle medium (Medium 41; Dainippon Pharmaceutical Co. Ltd.). Cells $\left(5 \times 10^{3}\right.$ per $\left.\mathrm{cm}^{2}\right)$ were plated on poly-L-lysine-coated glass cover slips adhered to a flexiperm disc (Greiner Bio-One GmbH, Göttingen, Germany). The medium was supplemented with $10 \%$ fetal bovine serum in a humidified atmosphere of $95 \%$ air and $5 \% \mathrm{CO}_{2}$ at $37^{\circ} \mathrm{C}$. The medium also contained antibiotics $(50 \mathrm{U} / \mathrm{ml}$ penicillin and $50 \mu \mathrm{g} / \mathrm{ml}$ streptomycin; SigmaAldrich, St. Louis, MO, USA) and was changed every 2 3 days.

\subsection{Measurement of the $\left[\mathrm{Ca}^{2+}\right] \mathbf{i}$}

The $\left[\mathrm{Ca}^{2+}\right] \mathrm{i}$ was measured with the $\mathrm{Ca}^{2+}$-sensitive fluorescent dye fura-2/AM (Dojindo Laboratories, Kumamoto, Japan). Cells were kept in a buffer comprising 135 $\mathrm{mM} \mathrm{NaCl}, 5 \mathrm{mM} \mathrm{KCl}, 1 \mathrm{mM} \mathrm{CaCl} 2,1 \mathrm{mM} \mathrm{MgCl}_{2}, 10$ $\mathrm{mM}$ glucose, and $20 \mathrm{mM}$ HEPES-NaOH (pH 7.4). They were loaded with the dye by incubation in $5 \mu \mathrm{M}$ fura2/AM for $45 \mathrm{~min}$ at $37^{\circ} \mathrm{C}$. Cells were then washed to remove excess fura-2/AM and then incubated in fresh buffer (without fura-2/AM) for $15 \mathrm{~min}$ after incubation to allow intracellular cleavage of the acetoxymethyl ester conjugate (and thus activation) of fura-2. Excitation light from a xenon lamp was passed through a filter $(340 \mathrm{~nm}$ or $360 \mathrm{~nm}$ ). The emission wavelength for analyses was $500 \mathrm{~nm}$. Changes in the fluorescence intensity of fura- 2 in cells were recorded with a video-imaging analysis system (FC-400, Furusawa Laboratory Appliance, Kawagoe, Japan). The $\left[\mathrm{Ca}^{2+}\right]$ i was determined as the ratio of the fluorescence stimulated by excitation at $340 \mathrm{~nm}$ or $360 \mathrm{~nm}$ compared with a standard calibration curve obtained using a Calcium Calibration Buffer Kit I (Molecular Probes, Eugene, OR, USA).

To minimize leakage of fura-2, cells were kept at $32^{\circ} \mathrm{C}$ during fluorescence measurements using a bath temperature controller (DTC-100A; DIA Medical Systems, Kunitachi, Japan). Cells were soaked in a flexiperm chamber containing $0.5 \mathrm{ml}$ of saline and perfused at 8.0 $\mathrm{ml} / \mathrm{min}$ with a tubing pump system (Master flex 7524-10; Cole-Parmer Instrument Company, Barrington, IL, USA). Drugs at appropriate concentrations were added to the perfusate. The drug-containing perfusates were switched by 6-Way Cock (Daiwa Co. Ltd., Matsumoto, Japan). To ensure that fura-2 fluorescence was maintained within the linear range (i.e., did not become saturated), we selected for analyses cells with a basal $\left[\mathrm{Ca}^{2+}\right] \mathrm{i}$ in the range $50-200 \mathrm{nM}$.

\subsection{Chemicals}

Tissue culture reagents were purchased from Gibco BRL (Rockville, MD, USA). Phenytoin (diphenyl hydantoin), NPS2390, U73122, TMB-8, and $m$-3M3FBS were purchased from Sigma-Aldrich. All other chemicals were supplied by Nacalai Tesque (Kyoto, Japan). These chemicals were dissolved in dimethyl sulfoxide (Sigma-Aldrich) as stock solutions, and thereafter added to the perfusate.

\subsection{Statistical Analyses}

Data are the mean \pm standard error of the mean (SEM) and the number of observations $(\mathrm{N})$. Statistical analyses of the data were undertaken by the Student's two-sided paired $t$-test. Differences between mean values were considered significant if the probability of error (p) was less than 0.05 .

\section{Results}

In order to determine whether or not phenytoin elevates the $\left[\mathrm{Ca}^{2+}\right] \mathrm{i}$ similarly to nifedipine, effects of phenytoin on the $\left[\mathrm{Ca}^{2+}\right] \mathrm{i}$ were examined. Phenytoin $(10-200 \mu \mathrm{M})$ concentration-dependently elevated the $\left[\mathrm{Ca}^{2+}\right] \mathrm{i}$, as shown in Figure 1.

The nifedipine-induced $\left[\mathrm{Ca}^{2+}\right]$ i elevation is evoked by 


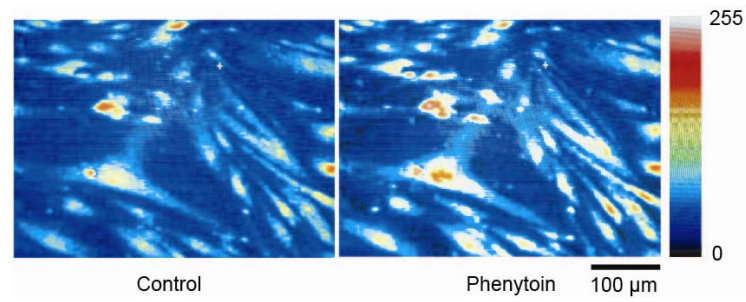

(a)

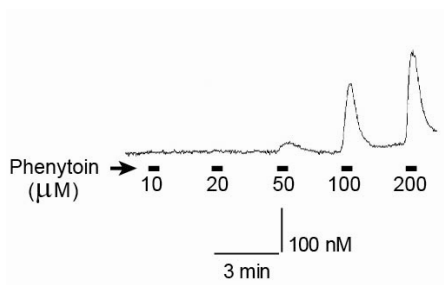

(b)

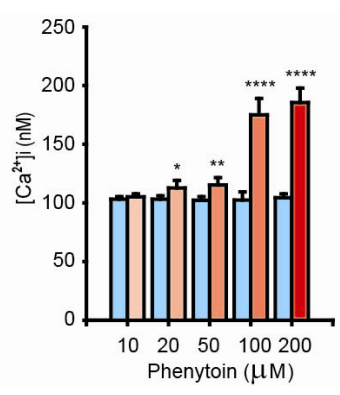

Figure 1. (a) Phenytoin-induced $\left[\mathrm{Ca}^{2+}\right]$ i elevation in gingival fibroblasts. Phenytoin $(100 \mu \mathrm{M})$ elevated the $\left[\mathrm{Ca}^{2+}\right] \mathrm{i}$, which was represented by pseudocolours (256 gradations); (b) Concentration-response relationship between phenytoin and the $\left[\mathrm{Ca}^{2+}\right]$ i. Phenytoin $(10-200 \mu \mathrm{M})$ concentration-dependently elevated the $\left[\mathrm{Ca}^{2+}\right]$ i. The left trace shows a representative time course of the $\left[\mathrm{Ca}^{2+}\right] \mathrm{i}$ in the case of phenytoin $(10-200$ $\mu M)$ application. Number of observations $(N)=27, " p<0.05$; p $<0.01 ;$ and ${ }^{* * * * *} \mathrm{p}<0.001$.

stimulating CaSRs (Hattori et al., 2011). We performed the experiments to ensure that CaSRs exist in gingival fibroblasts and to examine whether the extracellular $\mathrm{Ca}^{2+}$ is related to the phenytoin-induced $\left[\mathrm{Ca}^{2+}\right] \mathrm{i}$ elevation. As illustrated in Figure 2, the $\mathrm{Ca}^{2+}$-free saline inhibited the phenytoin $(100 \mu \mathrm{M})$-induced $\left[\mathrm{Ca}^{2+}\right] \mathrm{i}$ elevation. In addition, effects of NPS2390, a CaSR blocker, on the phenytoin-induced $\left[\mathrm{Ca}^{2+}\right] \mathrm{i}$ elevation were investigated. NPS2390 $(10 \mu \mathrm{M})$ significantly suppressed the phenytoin $(100 \mu \mathrm{M})$ induced $\left[\mathrm{Ca}^{2+}\right]$ i elevation, as shown also in Figure 2.

Because stimulation of CaSRs transmits signals to phospholipase C (PLC), which converts phosphatidyl inositol diphosphate $\left(\mathrm{PIP}_{2}\right)$ to inositol-1,4,5-triphosphate $\left(\mathrm{IP}_{3}\right)$ and then, stimulates $\mathrm{IP}_{3}$ receptors in ER (intracellular $\mathrm{Ca}^{2+}$ stores) and induces $\mathrm{Ca}^{2+}$ release from ER. Thus, actions of U73122, a PLC inhibitor, on the phenytoininduced $\left[\mathrm{Ca}^{2+}\right] \mathrm{i}$ elevation were examined. U73122 (10 $\mu \mathrm{M})$ inihibited the phenytoin $(100 \mu \mathrm{M})$-induced $\left[\mathrm{Ca}^{2+}\right] \mathrm{i}$ elevation. Furthermore, effects of TMB-8, a blocker of $\mathrm{IP}_{3}$ receptors of ER, were tested. TMB-8 $(100 \mu \mathrm{M})$ significantly depressed the phenytoin $(100 \mu \mathrm{M})$-induced $\left[\mathrm{Ca}^{2+}\right]$ i elevation, as shown in Figure 3.

On the other hand, $m$-3M3FBS $(20 \mu \mathrm{M})$, a PLC activator, enhanced the phenytoin $(100 \mu \mathrm{M})$-induced $\left[\mathrm{Ca}^{2+}\right] \mathrm{i}$ elevation, as illustrated in Figure 4.
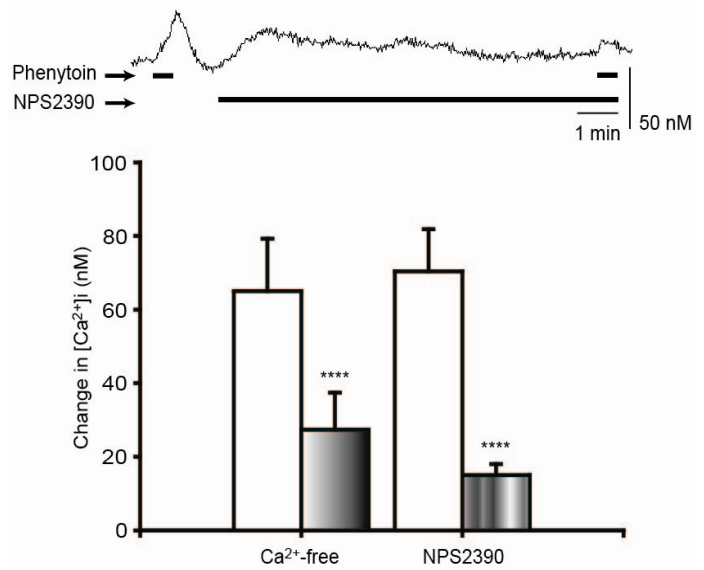

Figure 2. Inhibition of the phenytoin-induced $\left[\mathrm{Ca}^{2+}\right] \mathbf{i}$ elevation by a $\mathrm{Ca}^{2+}$-free saline and NPS2390. The $\mathrm{Ca}^{2+}$-free saline and NPS2390 (10 $\mu \mathrm{M})$, a CaSR antagonist, significantly inhibited the phenytoin-induced $\left[\mathrm{Ca}^{2+}\right]$ i elevation. The upper trace shows a representative time course of the $\left[\mathrm{Ca}^{2+}\right] \mathbf{i}$ in the case of NPS2390 $(10 \mu \mathrm{M})$ application. $N=20$ (a $\mathrm{Ca}^{2+}$-free saline), 28 (NPS2390), ${ }^{* * * *} \mathrm{p}<0.001$.
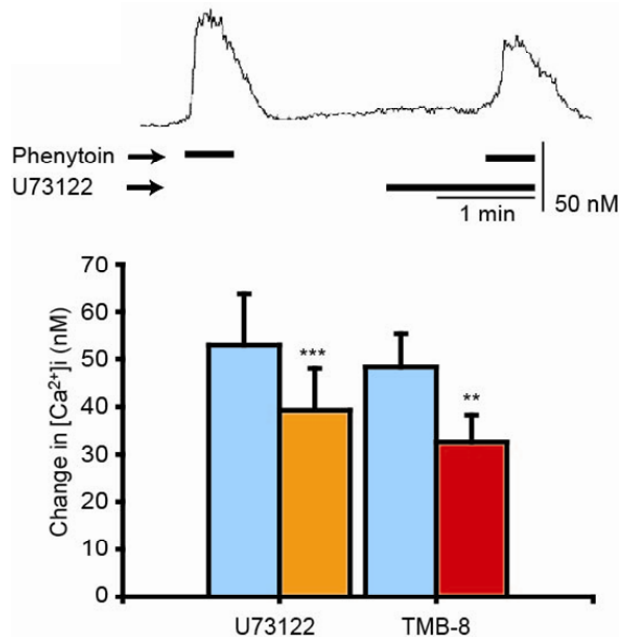

Figure 3. Inhibition of the phenytoin-induced $\left[\mathrm{Ca}^{2+}\right] \mathrm{i}$ elevation by $\mathrm{U73122}$ and TMB-8. U73122 $(10 \mu \mathrm{M})$, a phospholipase $\mathrm{C}$ inhibitor, and TMB-8 $(100 \mu \mathrm{M}), \mathrm{IP}_{3}$ receptor blocker in $\mathrm{ER}$, inhibited the phenytoin-induced $\left[\mathrm{Ca}^{2+}\right] \mathrm{i}$ elevation. The upper trace shows a representative time course of the $\left[\mathrm{Ca}^{2+}\right] \mathrm{i}$ in the case of $\mathrm{U73122}$ application. $\mathrm{N}=16$ in each case, ${ }^{* * *} p<0.01,{ }^{* * *} p<0.005$.

\section{Discussion}

Modéer et al. [9] reported that phenytoin elevates the $\left[\mathrm{Ca}^{2+}\right] \mathrm{i}$ under the condition of the normal extracellular calcium concentration. They claimed that there is relationship between phenytoin-induced alterations in $\left[\mathrm{Ca}^{2+}\right] \mathrm{i}$ in gingival fibroblasts and the clinical development of gingival overgrowth. To confirm the accuracy of this action, effects of phenytoin on the $\left[\mathrm{Ca}^{2+}\right] \mathrm{i}$ are under the same condition. Phenytoin elevated the $\left[\mathrm{Ca}^{2+}\right] \mathrm{i}$ in gingi- 


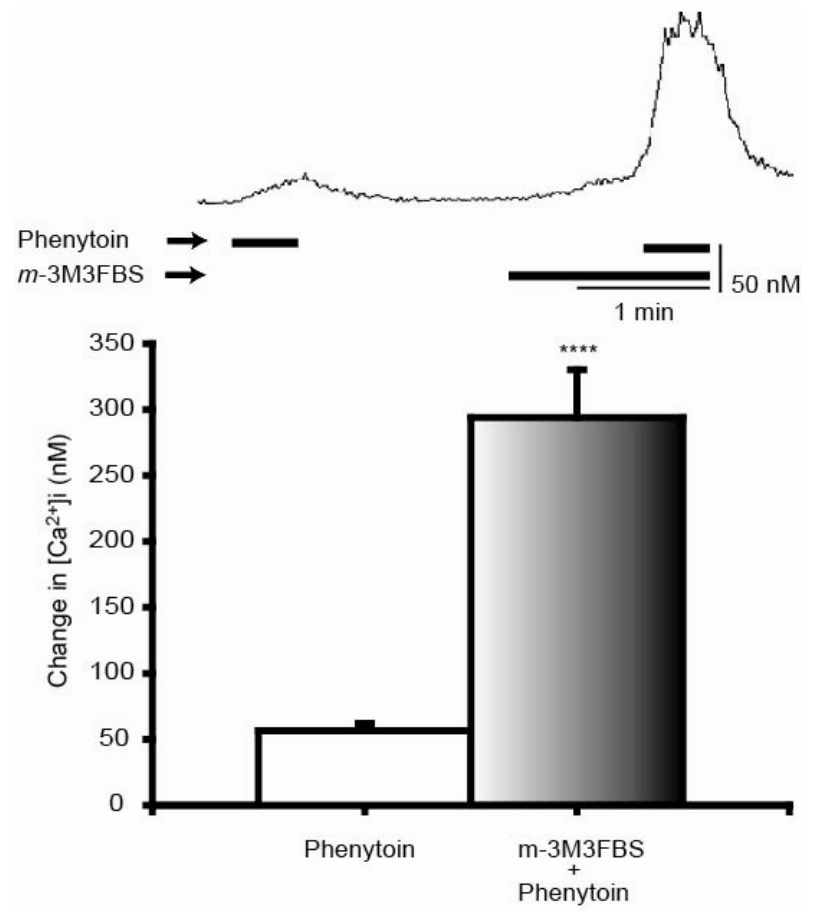

Figure 4. Enhancement of the phenytoin-induced $\left[\mathrm{Ca}^{2+}\right] \mathrm{i}$ elevation by $m$-3M3FBS. $m$-3M3FBS $(20 \mu M)$, a phospholipase $\mathrm{C}$ activator, enhanced the phenytoin-induced $\left[\mathrm{Ca}^{2+}\right] \mathrm{i}$ elevation. The upper trace shows a representative time course of the $\left[\mathrm{Ca}^{2+}\right] \mathrm{i}$ in the case of $\mathrm{m}-3 \mathrm{M} 3 \mathrm{FBS}$ application. $\mathbf{N}=\mathbf{2 4},{ }^{* * * * *} \mathbf{p}<\mathbf{0 . 0 0 1}$.

val fibroblasts and its action was concentration (10 - 200 $\mu \mathrm{M}$ ) dependent (Figures 1(a) and (b)).

Cell proliferation and progression through the cell cycle are $\mathrm{Ca}^{2+}$-dependent [14]. Munaron [15] concluded that most peptidic growth factors that bind to tyrosine kinase receptors and trigger complex intracellular signal transduction pathways finally leading to cell proliferation. Among the early events induced by growth factors, cytosolic calcium increase plays a key role. There are various mechanisms of $\left[\mathrm{Ca}^{2+}\right] \mathrm{i}$ elevation such as the $\mathrm{Ca}^{2+}$ release from ER and influx through VOCs (voltage-operated $\mathrm{Ca}^{2+}$ channels), ROCs (receptor-operated $\mathrm{Ca}^{2+}$ channels), and TRP (transient receptor potential) channels [16]. Kwak et al. [11] have insisted that the extracellular CaSR is expressed in mouse mesangial cells and modulates cell proliferation. Thus, we aimed at roles of CaSRs, since we had already pharmacologically confirmed that CaSRs exist in gingival fibroblasts by observing that CaSR agonists (gentamicin, neomycin, spermine, $\mathrm{LaCl}_{3}$, and verapamil) elevated the $\left[\mathrm{Ca}^{2+}\right] \mathrm{i}[10]$. Thus, effects of the $\mathrm{Ca}^{2+}$-free saline and NPS2390, a CaSR antagonist, were examined. The $\mathrm{Ca}^{2+}$-free saline and NPS2390 inhibited the phenytoin-induced $\left[\mathrm{Ca}^{2+}\right] \mathrm{i}$ rise (Figure 2). These results indicate that CaSRs exist in gingival fibroblasts and that CaSRs are involved in the phenytoin-induced $\left[\mathrm{Ca}^{2+}\right]$ i rise.

By finding out the stimulatory effect of the CaSR on $\mathrm{H}^{+} / \mathrm{K}^{+}$-ATPase activity in gastric parietal cells, Remy et al. [12] have reported that signals from CaSRs are transmitted to ER, which is prevented by TMB-8, an $\mathrm{IP}_{3}$ receptor blocker in ER. Thus, we examined effects of modulators of signal transmission from CaSRs to ER. Since stimulation of CaSRs induces PLC activation [12], effects of U73122, a phospholipase C inhibitor [17], were examined. U73122 depressed the phenytoin-induced $\left[\mathrm{Ca}^{2+}\right] \mathrm{i}$ elevation and furthermore, TMB-8, also inhibited the phenytoin-induced $\left[\mathrm{Ca}^{2+}\right] \mathrm{i}$ elevation (Figure 3). On the other hand, $m-3 \mathrm{M} 3 \mathrm{FBS}$, a phospholipase $\mathrm{C}$ activator [11], enhanced the phenytoin-induced $\left[\mathrm{Ca}^{2+}\right] \mathrm{i}$ elevation (Figure 4). PLC hydrolyzes $\mathrm{PIP}_{2}$ and yields $\mathrm{IP}_{3}$, which diffuses to ER [18] and releases $\mathrm{Ca}^{2+}$ from them [13]. From these facts, our observations show that the $\mathrm{Ca}^{2+}$ release from the ER is involved in the phenytoininduced $\left[\mathrm{Ca}^{2+}\right]$ i elevation.

From the findings obtained, we have concluded that phenytoin elevates the $\left[\mathrm{Ca}^{2+}\right] \mathrm{i}$ by activating $\mathrm{CaSRs}$ and enhancing the $\mathrm{Ca}^{2+}$ release from the $\mathrm{Ca}^{2+}$ stores in gingival fibroblasts.

\section{Acknowledgements}

This work was supported by Japan Society for the Promotion of Science [Grant-in-Aid for Scientific Research (C) 22592321].

\section{REFERENCES}

[1] E. Bondon-Guitton, H. Bagheri and J. L. Montastruc, "Drug-Induced Gingival Overgrowth: A Study in the French Pharmacovigilance Database," Journal of Clinical Periodontology, Vol. 39, No. 6, 2012, pp. 513-518. doi:10.1111/j.1600-051X.2012.01878.X

[2] A. S. Narayanan, D. F. Meyers and R. C. Page, "Regulation of Collagen Production in Fibroblasts Cultured from Normal and Phenytoin-Induced Hyperplastic Human Gingiva," Journal of Periodontological Research, Vol. 23, No. 2, 1988, pp. 118-121.

doi:10.1111/j.1600-0765.1988.tb01343.x

[3] C. M. Kanno, J. A. Oliveira, J. F. Garcia, A. L. Castro and M. M. Criverini, "Effects of Cyclosporine, Phenytoin, and Nifedipine on the Synthesis and Degradation of Gingival Collagen in Tuffed Capuchin Monkeys (Celbus paella): Histochemical and MMP-1 and -2 and Collagen I Gene Expression Analysis," Journal of Periodontology, Vol. 79, No. 1, 2008, pp. 114-122. doi:10.1902/jop.2008.070267

[4] M. F. Akhter, S. L. Quayum, A. B. Ali and Z. Mamoon, "Drug-Induced Gingival Overgrowth-Review," Bangladesh Journal of Physiology and Pharmacology, Vol. 25, No. 1-2, 2009, pp. 26-29.

[5] G. H. Cockey, J. A. Boughman, E. L. Harris and T. M. 
Hassel, "Genetic Control of Variation in Human Gingival Fibroblast Proliferation Rate," In Vitro Cellular and Developmental Biology, Vol. 25, No. 3, 1989, pp. 255-258. doi:10.1007/BF02628463

[6] O. A. González and J. M. González, "Morphological and Phenotypic Differences in Fibroblasts Obtained from Gingival Overgrowth Secondary to Phenytoin: A Pilot Study," Revista Odontológica Mexicana, Vol. 13, 2009, pp. 17-23.

[7] T. Kato, N. Okahashi, T. Ohno, H. Inaba, S. Kawai and A. Amano, "Effect of Phenytoin on Collagen Accumulation by Human Gingival Fibroblasts Exposed to TNF- $\alpha$ in $V i$ tro," Oral Desease, Vol. 12, No. 2, 2006, pp. 156-162. doi:10.1111/j.1601-0825.2005.01175.x

[8] Y. Fujimori, S. Maeda, M. Saeki, I. Morisaki and Y. Kamisaki, "Inhibition by Nifedipine of Adherence- and Activated Macrophage-Induced Death of Human Gingival Fibroblasts," European Journal of Pharmacology, Vol. 415, No. 1, 2001, pp. 95-103. doi:10.1016/S0014-2999(01)00810-X

[9] T. Modéer, G. Brunius, C. Mendez, L. Juntti-Beggren and P. O. Berggren, "Influence of Phenytoin on cytoplasmic Free $\mathrm{Ca}^{2+}$ Level in Human Gingival Fibroblasts," Scandinavian Journal of Dental Research, Vol. 99, No. 4, 1991, pp. 310-315.

[10] T. Hattori, T. Ara and Y. Fujinami, "Pharmacological Evidences for the Stimulation of Calcium-Sensing Receptors by Nifedipine in Gingival Fibroblasts," Journal of Pharmacology and Pharmacotherapeutics, Vol. 2, No. 1, 2011, pp. 30-35. doi:10.4103/0976-500X.77111

[11] J. O. Kwak, J. Kwak, H. W. Kim, K. J. Oh, Y. T. Kim, S. M. Jung and S. H. Cha, "The Extracellular Calcium Sensing Receptor Is Expressed in Mouse Mesangial Cells and Modulates Cell Proliferation," Experimental and Molecular Medicine, Vol. 37, No. 5, 2005, pp. 457-465. doi:10.1038/emm.2005.56
[12] C. Remy, P. Kirchhof, P. Hafner, S. M. Busque, M. K. Müller, J. P. Geibel and C. A. Wagner, "Stimulatory Pathways of the Calcium-Sensing Receptor on Acid Secretion in Freshly Isolated Human Gastric Glands," Cellular Physiology and Biochemistry, Vol. 19, No. 2, 2007, pp. 33-42. doi:10.1159/000099190

[13] O. Kifor, I. Kifor and E. D. Brown, "Effects of High Extracellular Calcium Concentrations on Phosphoinositide Turnover and Inositol Phosphate Metabolism in Dispersed Bovine Parathyroid Cells," Journal of Bone and Mineral Research, Vol. 7, No. 11, 1992, pp. 1327-1336. doi:10.1002/jbmr.5650071113

[14] M. A. Rodrigues, D. A. Gimes, M. F. Leite, W. Grant, L. Zhang, W. Lam, Y. C. Cheng, A. M. Bennett and M. H. Nathanson, "Nucleoplasmic Calcium Is Required for Cell Proliferation," Journal of Biological Chemistry, Vol. 282, No. 23, 2007, pp. 17061-17068. doi:10.1074/jbc.M700490200

[15] L. Munaron, "Calcium Signaling and Control of Cell Proliferation by Tyrosine Kinase Receptors (Review)," International Journal of Molecular Medicine, Vol. 10, No. 6, 2002, pp. 671-676.

[16] L. Munaron, S. Antoniotti and D. Lovisolo, "Intracellular Calcium Signals and Control of Cell Proliferation: How Many Mechanisms?" Journal of Cellular and Molecular Medicine, Vol. 8, No. 2, 2004, pp. 161-168. doi:10.1111/j.1582-4934.2004.tb00271.X

[17] Y. S. Bae, T. G. Lee, J. C. Park, J. H. Hur, Y. Kim, K. Heo, J. Y. Kwak, P. G. Suh and S. H. Ryu, "Identification of a Compound that Directly Stimulates Phospholipase C Activity," Molecular Pharmacology, Vol. 63, No. 5, 2003, pp. 1043-1050. doi:10.1124/mol.63.5.1043

[18] B. Srinu, O. Banji, M. Kumar, S. R. Teja and T. Praveen, "Cell Communication and Ion Channels: A Review," International Journal of Research in Pharmacy and Chemistry, Vol. 1, No. 1, 2011, pp. 91-100. 